\title{
Entrepreneurial Leadership of Young Independent Entrepreneurs in the Disruptive Era
}

\author{
Sadikun Citra Rusmana ${ }^{1,{ }^{*}}$ Hari Mulyadi ${ }^{2}$ \\ ${ }^{1}$ Universitas Pasundan \\ ${ }^{2}$ Universitas Pendidikan Indonesia \\ *Corresponding author.Email: sadikuncitrarusmana@yahoo.com
}

\begin{abstract}
Entrepreneurial leadership have four characteristics are lead the vision, encourage, arrange, and direction. The whole set of characteristics should be observed in relation to company success and creativity. This paper presents the results of study in entrepreneurship issue in uncertainty business of young businessman, especially those who were in the age of 19 to 30. It also investigates the importance of innovation to the success of a business. Descriptive and verificative method were applied in this study by observing 33 respondents who were running the business in creative industry such as foods, architecture, arts, etc. The participants were mainly 24 of men and 9 of women. The findings of the study showed that innovation and risks correlated to entrepreneurial leadership without significantly involving gender. Entrepreneurial leadership has been identified as the best solution to unemployment, underemployment and poverty among young people, particularly in entrepreneur's community who run a business independently.
\end{abstract}

Keywords: Entrepreneurial Leadership, Innovation, Risk.

\section{INTRODUCTION}

Entrepreneurial leadership has four major characteristics such as lead the vision, encourage, arrange, and direction [1]. They have been identified as the best solution to unemployment, underemployment and poverty among of young people [2]. This skill could shape distinctive characteristics to those who are involved in entrepreneur's community, particularly in running self-business because they will be able to transform low value resources into the higher ones with adequate risk through effective leadership [3].

In Indonesia, entrepreneurs who have leadership skill and strong motivation are required to accelerate and establish regional economy, particularly related to the cases of young independent entrepreneurs in West Java [4]. They need to face the Disruption Era volatile, uncertainity, complexity, and ambiguity [5]. Entrepreneurship characteristic is analogized as a virus that affects someone to get better in doing anything possible with measurable risks. In the practice, entrepreneurial leadership offers an approach in which directors envisage, find, seize, and exploit opportunities [6].
Currently, governments all over the world are looking at entrepreneurship as a way to increasing the wealth and well-being [7]. Entrepreneurship is a dynamic process of vision, change and creation. It requires an implementation of energy and passion toward the creation and implementation of new ideas and creative solution [6]. An individual establishes a self-imposed norm that is not competitive with others. He sets realistic and challenging goals and likes to get feedback on how well he is going to improve performance. An entrepreneur needs to learn about investment in new techniques, to be adaptable, to have a professional attitude, and innovation [8] page 43. Innovation is known as a process to make something new and different products or services. It is the ability to apply creative solution to those problems and opportunities to enhance people's live [9] p. 51. Entrepreneurial leadership as a new model of leadership style in study of strategic entrepreneurship consists of three parts, namely (1) entrepreneur leadership as style of leadership, (2) entrepreneurial leadership as an entrepreneurial mindset, (3) entrepreneurial leadership as interface of two domains [10]. Every activity, like business for profit or social and government organization faces some risks in running their business. Risk refers to a probability of major financial loss [11]. 
This study, therefore, highlights three main lines of research (1) the creation of opportunities; (2) the characteristics that differentiate individuals who discover these opportunities; and (3) the ways of thinking and acting involved in the exploration of these opportunities [12]. These three theoretical strands define entrepreneurship as a dynamic process through which companies explore opportunities that have not been identified or explored by others, driven by a behaviouroriented strategy to the incremental creation of wealth; entrepreneurship is directly related to economic opportunities [13]. Global Entrepreneurship Monitor (GEM) and National Expert Survey (NES) provides standardized scales of national entrepreneurship. According to some experts, GEM is "someone who directly involves in delivering and assessing a major aspect of entrepreneurial condition in his/her country. The national experts could be politician, academics, entrepreneurs, government official, or other professionals in the field of entrepreneurship. The variables of this study are described in the following [14].

New entrepreneurs (18 to 40 years old who were involved in nascent business or young firm start-up). They are also known as active personnel, full or partial owners, and no salaries paid for over three months. Meanwhile, the hypotheses of this study are Innovation and Risk Factors positively relates with Entrepreneurial Leadership.

\section{METHODS}

This study involved young independent entrepreneurs in West Java, Indonesia. They have same criteria who run small business as the independent owner and got Mandiri Award from Bank Mandiri, in 2007 - 2010. The data were collected from the book authored by reference [15] entitled "Wirausaha Mandiri, book 1 and 2 (2009), and some other open resources. The respondents were required to answer some questions through email and direct oral explanation.

The study also aims to find the relation between two independent variables such as innovation (X1) and risk factors (X2) with entrepreneurial leadership (Y). Descriptive statistics and Pearsons correlation were computed by using the SPSS version 20. To measure innovation and risk factors in relation with style of entrepreneurial leadership, this study employed entrepreneurial strategy matrix model (Sonfield \& Lussier, 2007). In this model, innovation as vertical and risk as horizontal in the quadrant models. I acts as high innovation, $\mathrm{i}$ is low innovation, $\mathrm{R}$ is high risk and $\mathrm{r}$ is low risk. The data were analysed by using Likert's Scale from 1 (low) to 5 (High).

\section{RESULTS AND DISCUSSION}

The findings of this study showed that there were four quadrans, namely I $-\mathrm{r}$ (high innovation - low risk, $\mathrm{I}-\mathrm{R}$ (high innovation - high risk), $\mathrm{R}-\mathrm{i}$ (high risk low innovation), and $\mathrm{i}-\mathrm{r}$ (low innovation - low risk), based on Fig.1.

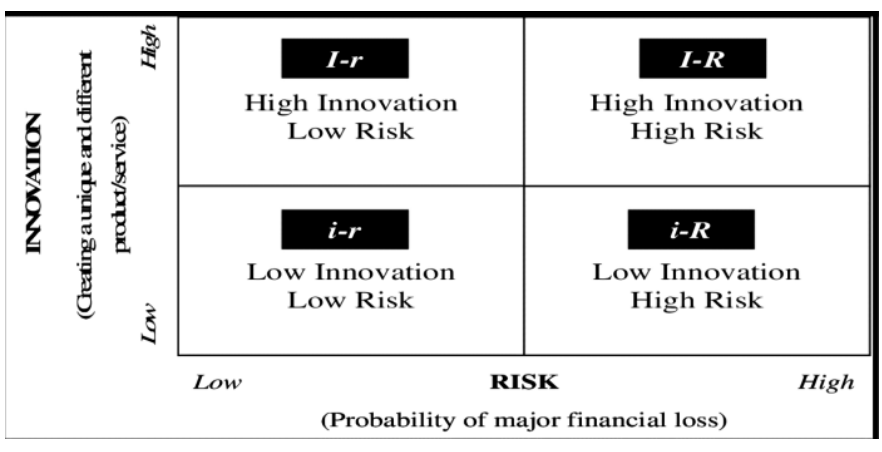

Figure 1 Four quadrans

Source: [11]

The 33 respondents acted as entrepreneurs, stay in five area clusters of West Java region. They were 21 38 old and running on their business in trading and services, fashions, and food \& beverage.

Regarding the innovation, their perception number was 4,17 indicating high criteria. The innovation focused on customer relation, without involving invention and new segmentation of consumers. The number of perceptions on risk factors was 4,02 implying high criteria. They could handle the employee and customers complains, but not in a financial management. Their entrepreneurial leadership perceptions with four indicators (lead the vision, encourage, arrange, and direction) was 4,30 showing very high criteria. The entrepreneurs perceived business as a part of social awareness, and ready to share to others. However, they though that running business is not an easy job. They tried to open more markets with the same network business in the same industry. The ideal condition on quadrant model or entrepreneurial strategy of $\mathrm{X}$ matrix is $\mathrm{I}-\mathrm{r}$ (high innovation - low risk). It was considered as an appropriate strategy putting entrepreneurs on a fixed selection of strategy in the business. The entrepreneurs generally tried to be less risky and increased their innovation. But in this study, entrepreneurs on position I - R (high innovation - high risk). In regard to the correlation variables, entrepreneurial leadership to innovation showed the number of 0,252 and the risk was 0,026 . Both of independent and correlation variables had positive influence on the dependent variables. This study found that innovation and risk had positive relation to the entrepreneurial leadership. If the innovation and risk were high, then it could increase the leadership skill in entrepreneurs as they run the business. 
Entrepreneurs are the people who have high entrepreneurial leadership. They have a vision to attract others and be distinctive from others. The entrepreneurship is the ability to influence and guide people to achieve the organizational goals. Young independent entrepreneurs should maximize their resources, but they could not do it in the best because the business setting change fast, and it needs immediate adjustment. High innovation and risk show correlation, innovation, and high risks. It requires the entrepreneurs to manage according to principle of high innovation with low risk, in accordance with the entrepreneurial strategy matrix model proposed [11]. We already know that they recommend the strategy is I - $r$ (high innovation - low risk) as an appropriate and suitable strategy.

\section{CONCLUSIONS}

More young entrepreneurs have some problems for runs the business in disruptive era. They need to be more innovative and create some better improvements. Entrepreneurial leadership may help them to run the business since it provides high innovation and risks.

\section{ACKNOWLEDGMENTS}

The authors would like to appreciate the Dean of Economic and Business Faculty, University of Pasundan for their financial and administrative support to undertake this project. We would like to thank all colleagues particularly those who have kindly provided the respondents good cooperation in data collection.

\section{REFERENCES}

[1] Susanto, Leadpreneurship. Strategic management approach in Entrepreneurship. Jakarta: Esensi of Erlangga, 2009.

[2] B. N. Neneh, "From entrepreneurial intentions to behavior: The role of anticipated regret and proactive personality," J. Vocat. Behav., 2014, doi: 10.1016/j.jvb.2019.04.005.

[3] Y. Esmer and F. Dayi, "Entrepreneurial leadership a theoretical framework," 2018, doi: 10.20472/iac.2016.025.020.

[4] Wirasasmita and Lupiyadi, Culturepreneurship. Jakarta: Mitra Wacana Media, 2016.

[5] Musrry and Kartajaya, Marketing in era of VUCA. Gramedia, 2018.
[6] H. Frederick, A. O'Connor, and D. F. Kuratko, Entrepreneurship Theory, Process and Practice. 2014.

[7] N. Langowitz and M. Minniti, "The entrepreneurial propensity of women," Entrep. Theory Pract., 2007, doi: 10.1111/j.15406520.2007.00177.x.

[8] Timmon and Spinelli, Entrepreneurship for the 21st.Century, Eight. New York: Mc.GrawHillIrwin, 2009.

[9] T. Zimmerer, Entrepreneurship and The New Venture Formation. Prentice Hall, 1996.

[10]C. Harrison and C. Harrison, "Leadership Research and Theory," in Leadership Theory and Research, 2018.

[11]M. C. Sonfield and R. N. Lussier, "The entrepreneurial strategy matrix: A model for new and ongoing ventures," Bus. Horiz., 1997, doi: 10.1016/S0007-6813(97)90055-0.

[12]Moris, Corporate entrepreneurship and innovation, 2rd ed. South Western.: Thomson, 2008.

[13] M. Hitt and R. D. Ireland, "The Intersection of Entrepreneurship and Strategic Management Research," in The Blackwell Handbook of Entrepreneurship, 2003.

[14]S. Kelley and Herrington, "Global Entrepreneurship Monitor: Global Report 2011," 2011.

[15] R. Kasali, Independent young entrepreneurs, the story about young people who overcomes fear and friendly with uncertainty. Jakarta: Gramedia, 2010.

[16] R.D Hisrich, Entrepreneurship, 7nd edition. Mc. GrawHill Education, 2008

[17] Kuratko et. al. "Managers' corporate entrepreneurial actions and job satisfaction," Int Entrep Manag J; 1 (3):275-91, 2005

[18]Lombardi, Strategic. entrepreneurship: personal values and characteristics influencing smes' decision-making and outcomes. The gemar balloons case, 2020 